\title{
Peertechz
}
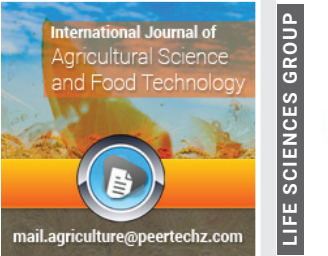

\section{Evaluation and Demonstration of Different Feeding options for Borana Cattle Fattening}

\author{
Aman Gudeto*, Tesfaye Alemu T, Genet Dadi, Ashebir \\ Worku, Mieso Guru and Frehiwot Mesele
}

Oromia Agriculture Research Institute (IQQO), Adami Tulu Agricultural Research Center, Ethiopia

Received: 03 September, 2020
Accepted: 11 December, 2020
Published: 14 December, 2020

*Corresponding author: Aman Gudeto, Oromia Agriculture Research Institute (IQQO), Adami Tulu Agricultural Research Center, Ethiopia,

E-mail: amangude13@gmail.com

Keywords: Borana beef; Young bulls fattening; Feeding options; Cattle

https://www.peertechz.com

\begin{abstract}
Evaluation and demonstration study was conducted at Kemo-Gerbi kebele of Adami Tulu Jidokombolcha district on two to three year old Borana bulls with the objectives of evaluation and demonstration of bulls fattening technologies at on-farm level. One Farmer's Research Extension Group (FREG) was formed for fattening the bulls. Twenty bulls were purchased from Borana zone by farmers for the fattening trials. Two feeding treatments $\left(T_{1}=\right.$ crushed maize grain $(20 \%)+$ wheat bran $(45 \%)+35 \%$ Noug seed cake and $\mathrm{T}_{2}=$ wheat bran $(65 \%)+$ cotton seed cake $(35 \%)$ ) were evaluated at on- farm. Eight hour grazing was common for both treatments. The animals were randomly assigned for dietary rations and data on live weight change of the animals were taken using weight chart tape (developed by JICA project). Finishing weights, total weight gain and daily weight gain of the bulls were not different $(P>0.05)$ between the treatments. Bulls fed on treatment one attained an average daily weight gain of $0.83 \mathrm{~kg}$ per bull; while bulls fed on treatment two gained $0.76 \mathrm{~kg}$ per bull per day. Total gross margin of treatment one (53,154.5 ETB) was higher than treatment two $\left(49,467.75\right.$ ETB). Cost-benefit analysis showed that feeding option number one $\left(T_{1}\right)$ is more profitable than bulls fed on $T_{2}$. However, fatteners can use any of the feeding options depending on availability of the ingredients in their area.
\end{abstract}

\section{Introduction}

Ethiopia has large livestock population in Africa. Its cattle, sheep and goat population are estimated above 59.5, 30.7 and 30.2 million heads, respectively [1]. The livestock sector contributes about $15 \%$ of the total export income and $30 \%$ of agricultural employment [2]. In spite of the importance, this sector has remained undeveloped and in many cases underutilized [3].

The average Ethiopian beef yield per animal of $108.4 \mathrm{~kg}$ is by far less than $119 \mathrm{~kg}$ for Sudan, 146 for Africa and $205 \mathrm{~kg}$ for whole world [4-6]. Ethiopian people meat consumption percapita is $13.9 \mathrm{~kg} /$ year which lower than the Africa (27 kg/year) and the world averages (100 kg/year) [7]. This is due to fact that livestock production in Ethiopia is subsistence oriented and characterized by low production performances.

The total amount of meat presently produced from cattle production in the Ethiopia could not promise the increasing demand of people. On the other hand, the traditional livestock practices are not mostly market oriented [8]. Farmer cattle fattening practices are frequently dependents on natural grazing land and crop residues with few or no supplements. The traditional practices did not also consider for the animal nutrient requirement, the level of feeding being either above or below the animal requirements.

The government of Ethiopia is trying to expand the sector to meet the increased demand from both export and domestic markets. Inline to this, some fattening feed options are generated at Adami Tulu Agriculture Center. Recent reports indicated that growth performance of two years old Borana beef evaluated on different dietary ration managed to attain $300 \mathrm{~kg}$ have promising results [9]. Evaluation and demonstration of such technology is a way to promote to farmers and users. Therefore, the study was designed to evaluate and demonstrate beef fattening technologies at on-farm level.

\section{Objectives}

- To evaluate and demonstrate fattening technologies for young Borana bulls at on-farm level 
- To identify most economical feeding option for young Borana bulls at on farm level

\section{Methodology}

\section{Demonstration site}

The study was conducted in East Shoa Zone. East Shoa Zone is belongs to the administrative zone of Oromia regional state, Ethiopia. The zone has an area of $10421 \mathrm{~km}^{2}$. There are 10 districts within this zone and Adami Tulu JidoKombolcha (ATJK) is one of the districts, where the demonstration was undertaken. ATJK is found in mid-rift valley of Oromia Regional State at $167 \mathrm{~km}$ from Addis Ababa, Ethiopia at an altitude of 1650 meter above sea level, along the main road to Hawassa town. The district is geographically located at latitude of 70 50' North and longitude of 380 42'East [10]. Kemo-Gerbi kebele was purposely selected together with livestock expert of ATJK district livestock agency having farmers with cattle fattening experience and access to market and transport. Cattle fattener primary selection criteria are willingness, history and accessibility to market.

\section{Farmers' selection and capacity building}

The activity was conducted using the Farmers' Research Extension Group (FREG) approaches. One FREG was organized. Farmers were selected based on their willingness to participate and previous experience with cattle fattening. Farmers contributed money to purchase bulls, grazing land, construct fattening shade and labor for the fattening purpose. Adami Tulu Agriculture Research Center provided dietary ration (concentrate feeds) and technical aids during the fattening period. The theoretical and practical training were given to farmers, district livestock development experts and development agents on mixed ration preparation, feeding management, animals' health keeping, bulls fattening and marketing the finished bulls.

\section{Experimental animals' selection and feeding manage- ment}

Ages of the bulls were determined by dentition techniques. Accordingly, the bulls were two to three years old with an average initial live weight of $216.6 \pm 12.9 \mathrm{~kg}$. A total of 20 bulls were purchased from Borana Zone of Oromia Regional State, Ethiopia. They were transported by truck to the study site. The experimental bulls were injected anti-parasites before the beginning of the actual feeding. All experimental bulls were randomly assigned to one of the two dietary treatments as indicated below in the next section. The dietary ration was prepared and provided in individually feeding bases. The concentrates were supplemented to the bulls at a rate of $2.5 \%$ of their life weights and readjusted on every 15 days weight recorded. The animals were kept on grazing for eight hours a day plus few tinning of maize crop whenever available and watering was freely or adlib during the whole day.

\section{Experimental ration formulation}

Dietary rations were formulated from different feed ingredients; wheat bran, Noug Seed Cake (NSC), crushed maize grain and Cotton Seed Cake (CSC). Two dietary rations ((Treatment 1: Eight hour grazing + crushed maize grain (20\%) + wheat bran $(45 \%)+35 \%$ NSC and (Treatment 2: Eight hour grazing $+35 \%(\mathrm{CSC})+65 \%$ wheat bran) $)$ were formulated in such a way that they contain similar amounts of energy and protein as compared to the traditional one, which is usually mixed at random (not in proportion manner) or fed separately and as being available; also mostly not depends agro - products that use only natural pasture Table 1 .

\begin{tabular}{|c|c|c|c|c|}
\hline Table 1: Feeds composition (\%). \\
\hline Dietary ration & Ingredient & Dry Matter & CP & TDN \\
\hline & Crushed maize grain $(10,85)$ & 20 & 2.00 & 17.00 \\
\hline \multirow{2}{*}{$\mathrm{T}_{1}$} & Wheat bran $(13,67)$ & 45 & 5.85 & 30.15 \\
\hline & Noug seed cake $(29.75,66)$ & 35 & 10.41 & 23.10 \\
\hline & Total & 100 & 18.26 & 70.25 \\
\hline & Wheat bran $(13,67)$ & 65 & 8.45 & 43.55 \\
\hline \multirow{2}{*}{$\mathrm{T}_{2}$} & Cotton seed cake $(28,75)$ & 35 & 9.80 & 25.25 \\
\hline & Total & 100 & 18.25 & 69.8 \\
\hline
\end{tabular}

$T_{1}$ Treatment One; $T_{2}$ Treatment Two; CP: Crude Protein; TDN: Total Digestible Nutrient

\section{Growth performance assessment}

Record sheets and check lists were prepared to collect data on the amount of feed offered and fortnightly live weight changes in kg. Growth performance of young bulls was assessed as below:

$$
\mathrm{DW}=\frac{(F B W-I B W)}{\mathrm{TD}}
$$

TWG $=$ FBW - IBW

Where: DG = Daily gain, TWG = Total weight gain, FBW = Finished body weight, IBW = Initial body weight and TD = Total feeding days

\section{Cost-benefit ratio analysis}

The variable costs incurred during conducting the evaluation and demonstration the beef fattening technologies were properly recorded. Thus costs like bulls purchase, transportation, concentrate purchase, wage and veterinary costs were considered in the financial analysis. The gross revenues were obtained from prices of the finished bulls sold at market. Fixed costs incurred for feeding the animals were excluded in financial analyses.

\section{Data analysis}

The collected data was input to computer. Growth performances and financial parameters incurred during evaluation and demonstration of different feeding options for young Borana bulls were analyzed using $\mathrm{t}$-test of $\mathrm{R}$ software 3.5.2 version.

\section{Result and discussion}

Effect of feeding different options on growth performance 
Effect of feeding different options on growth performances of the two to three years old Borana bulls were analyzed after finishing. The final body weight, total body weight and daily weight gains of the bulls were as listed in Table 2.

The study results indicate that there is no significance difference in final body weight between the two treatments. The current finding is related with the report of Mieso [11] who conducted similar study on the yearling Borana bulls. Similarly, Girma [9] reported that dietary rations have similar effect on final body weight of two years old Borana bulls.

The total and average daily weight gains for the experimental bulls didn't also showed significant difference between the two treatments at 105 days of fattening. Different authors [9,1115] conducted studies at on-station on yearling Borana bulls, two years old Borana bulls, yearling Kereyu bulls, two years old Kereyu bulls, yearling Arsi bulls and two years old Arsi bulls fed on similar dietary ration reported no significant differences in total weight gains between the treatments. The current average daily weight gains of the bulls was found to be similar to the reports of Girma [9] who indicated that 0.801 and $0.753 \mathrm{~kg}$ for two years old Borana bulls. Furthermore, this study indicated that the Borana bulls can attain export market body weight demand in 105 days of feeding Figures 1,2.

\section{Cost-benefit analysis}

The financial analysis of young Borana bulls after fattening period is listed in the Table 3. Even though, there was no significance difference between both treatments. The finding results indicated higher total gross margin for experimental bulls fed dietary feed $\left(T_{1}\right)$ than those fed dietary ration $\left(T_{2}\right)$. The study result was similar to Mieso [11] where the Borana bulls, which taken crushed maize grain, provided better profit than those received cotton seed cake.

\section{Farmers' opinion on the technology}

Farmers have their own opinion on the cattle fattening technologies. They have own observation on difference between their traditional fattening experience and the current fattening. In this study, participant farmers have appreciated the efficiency of the fattening ration in changing body condition of the animals. They also loved the processes involved animal selection criteria, feeding management, dietary ration preparation and the house construction. The fattening treatments were as also found to be profitable and easily manageable by farmers.

\section{Conclusion and Recommendation}

Twenty Borana bulls were randomly assigned in to two dietary ration groups and kept on feeding for 105 days to observe their growth performance. Both dietary rations have similar effect on growth performance of the young Borana bulls, which may be attributed to the similarity of the CP and TDN of the ration provided to the experimental bulls as well as the similarity of the breed. Numerically bulls fed on dietary $\mathrm{T}_{1}$ were more profitable than bulls fed on dietary $\mathrm{T}_{2}$. The two - three years age Borana bulls have potential to reach three hundred kilogram using the treatments within fifteen weeks of feeding.
Table 2: Body weight change during bulls fattening period.

\begin{tabular}{|c|c|c|c|}
\hline Weight $\mathbf{( K g )}$ & $\mathbf{T}_{1}$ & $\mathbf{T}_{2}$ & Overall \\
\hline Initial body weight & $214.3 \pm 10.9$ & $218.8 \pm 14.7$ & $216.6 \pm 12.9$ \\
\hline Final body weight & $301.6 \pm 7.8$ & $298.1 \pm 10.9$ & $300.3 \pm 9.4$ \\
\hline Total weight gain & $87.3 \pm 5.2$ & $79.3 \pm 8.4$ & $83.8 \pm 7.7$ \\
\hline Average daily gain & $0.83 \pm 0.07$ & $0.76 \pm 0.08$ & $0.79 \pm 0.07$ \\
\hline
\end{tabular}

Values are not significant across raw at $P<0.05$

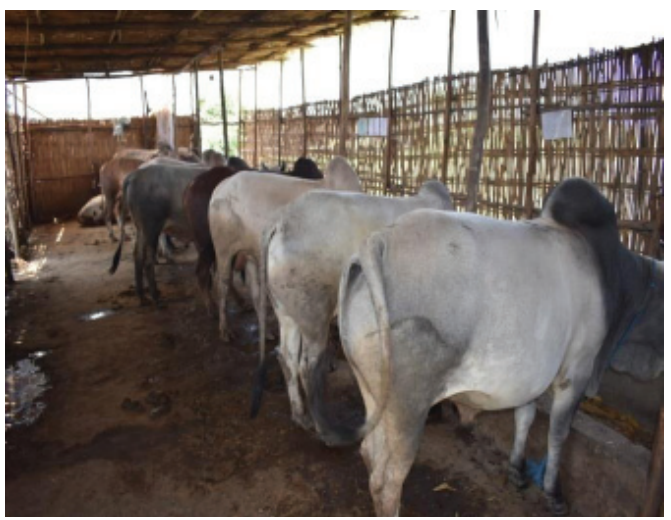

Figure 1: Bulls at fattening shade.

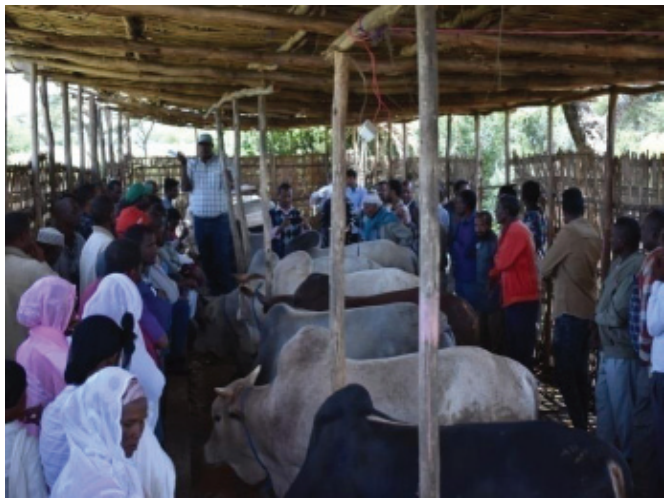

Figure 2: Farmers field-day.

Table 3: Economic return from Borana bulls fattening at on-farm level.

\begin{tabular}{|c|c|c|c|}
\hline List of items (ETB) & $\mathbf{T}_{\mathbf{1}}$ & $\mathbf{T}_{\mathbf{2}}$ & Overall \\
\hline Feeds costs per bull & $4,635.05$ & $4,798.43$ & $4,716.74$ \\
\hline Purchasing price per bull & 8,500 & 8,500 & 8,500 \\
\hline Transport cost per bull & 700 & 700 & 700 \\
\hline Labor cost per bull & 150 & 150 & 150 \\
\hline Veterinary cost per bull & 55 & 45 & 50 \\
\hline Total variable cost per bull & $14,040.05$ & $14,193.43$ & $14,116.74$ \\
\hline Total gross output per bull & $19,355.50$ & $19,140.20$ & $19,247.85$ \\
\hline Gross margin per bull & $5,315.45$ & $4,946.77$ & $5,131.11$ \\
\hline Total gross margin & $53,154.5$ & $49,467.75$ & $51,311.13$ \\
\hline
\end{tabular}

ETB: Ethiopia Birr; Values are not significant across raw at $P<0.05$

Therefore, we recommend that any one of the dietary rations can be used based on the availability of the feed ingredients in the fattening locations as there were no significant variations in major parameters between the treatments. 


\section{Acknowledgment}

The authors would like to thank, Ethiopian Institute of Agricultural Research (EIAR) for funding this activity financially through national beef research program and Oromia Agricultural Research Institute (OARI) for the logistic support to accomplish the activity as well as the development agents and farmers for their valuable contribution and cooperation during the entire course of the on-farm feeding trial experimentation.

\section{References}

1. Central Statically Agency (CSA) (2017) Ethiopia Sample Survey Enumeration. Addis Ababa. Ethiopia. FAO (Food and Agriculture Organization of the United Nations) data, 2005. Rome, Italy.

2. Ayeneshet B, Abera M, Wondifraw Z (2018) Reproductive and Productive Performance of Indigenous Dairy Cows under Smallholder Farmers Management System in North. J Fisheries Livest Prod 6: 261. Link: https://bit.ly/378PoJ2

3. Mezgebe G, Gizaw S, Urge M, Chavhan A (2017) Begait cattle production systems and production performances in northern Ethiopia. Int J Life Sciences 5: 506-516. Link: https://bit.ly/379msAJ

4. Negassa A, Shahidur R, Gebremedhin B, Headquarters I (2011) Livestock Production and Marketing in Ethiopia. Ethiopia Strategy Support Program II, ESSP II Working Paper 26-35. Link: https://bit.ly/3qINNkO

5. Mummed YY, Edward Cottington Webb (2015) Carcass quality audit - A strategy to improve beef sector in Ethiopia. African Journal of Agricultural Research 10: 2731-2737. Link: https://bit.ly/2Wb41oE

6. Yesihak YM, Webb EC (2015) Causes of Beef Carcass and Organ Condemnations in Ethiopia. Asian Journal of Animal and Veterinary Advances 10: 147-160. Link: https://bit.ly/3gHeS3u

7. Tsigereda F, Mengistu U, Emebet M (2016) Assessment of Traditional Cattle
Fattening Practices in Hararghe Highland Parts of Ethiopia. World Journal of Agricultural Science 12: 149-160.

8. Belay Z, Minale G (2017) Traditional Cattle Husbandry Practice in Gamo Gofa Zone, Southern Western Ethiopia. International Journal of Novel Research in Life Sciences 4: 1-7. Link: https://bit.ly/3oHXZIA

9. Girma D, Mieso G, Tesfaye Alemu T, Arse G, Frehowit M, et al. (2015) Effect of different feeds option on growth response and carcass characteristic of two years aged Borana bulls for export market weight gain at Adami Tulu Agricultural Research Center. Basic Research Journal of Agricultural Science and Review 4: 139-145.

10. Shiberu E, Hailu HK, Kibret K (2019) Comparative Evaluation of Small Scale Irrigation Schemes at Adami Tulu JidoKombolcha Woreda, Central Rift Valley of Ethiopia. Irrigation \& Drainage Systems Engineering 8. Link: https://bit.ly/37ckGP8

11. Mieso G, Girma D, Tesfaye Alemu T, Frehiwot M, Tesfaye Alemu A (2013) Evaluation of different feeding options on yearling Borana bulls to attain export market weight at Adami Tulu Agricultural Research Center. American Journal of Cell and Animal Biology 1: 01 -09. Link: https://bit.ly/3mciVWD

12. Ashebir W, Tesfaye A, Mieso G, Aman G, Frehiwot M, et al. (2019) Evaluation of different feeding options on growth response and carcass characteristic of yearling Kereyu-bulls to attain local/export market weight. Int J Agric Sc Food Technol 5: 050-053. Link: https://bit.ly/2JOvtGB

13. Tesfaye Alemu T, Tesfaye Alemu A, Girma D, Mieso G, Ashebir W, et al. (2018) Evaluation of different dietary rations for growth performance and carcass characteristics of two years old Kereyu bulls for export/local market weight. Basic Research Journal of Agricultural Science and Review 6: 49-56.

14. Aman G, Tesfaye A, Mieso G, Ashebir W, Genet D (2019) Evaluation of Different Feeding Options for Yearling Arsi Bulls to Attain Export Market Weight. Journal of Biology, Agriculture and Healthcare 19. Link: https://bit.ly/37URSKi

15. Tesfaye T, Ashebir W, Genet D, Mieso G, Aman G (2019) Evaluation of different feeding options for growing two years old Arsi-Bulls to attain export market weight. Basic Research Journal of Agricultural Science and Review 7: 11-17.
Discover a bigger Impact and Visibility of your article publication with Peertechz Publications

Highlights

* Signatory publisher of ORCID

* Signatory Publisher of DORA (San Francisco Declaration on Research Assessment)

* Articles archived in worlds' renowned service providers such as Portico, CNKI, AGRIS, TDNet, Base (Bielefeld University Library), CrossRef, Scilit, J-Gate etc.

* Journals indexed in ICMJE, SHERPA/ROMEO, Google Scholar etc.

* OAI-PMH (Open Archives Initiative Protocol for Metadata Harvesting)

* Dedicated Editorial Board for every journal

* Accurate and rapid peer-review process

* Increased citations of published articles through promotions

* Reduced timeline for article publication

Submit your articles and experience a new surge in publication services (https://www.peertechz.com/submission).

Copyright: @ 2020 Gudeto A, et al. This is an open-access article distributed under the terms of the Creative Commons Attribution License, which permits unrestricted use, distribution, and reproduction in any medium, provided the original author and source are credited. 